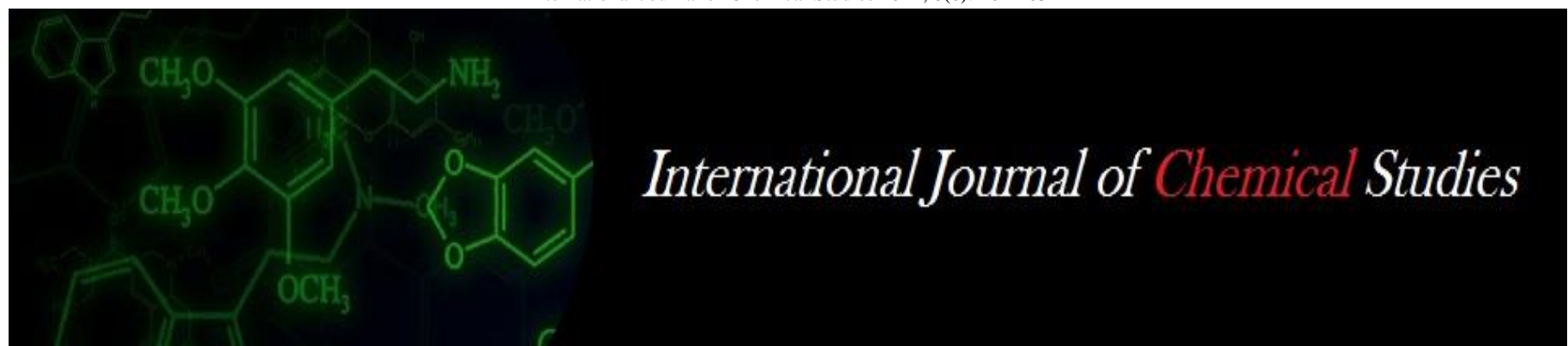

P-ISSN: 2349-8528

E-ISSN: 2321-4902

www.chemijournal.com

IJCS 2021; 9(1): 261-263

(C) 2021 IJCS

Received: 03-10-2020

Accepted: 08-11-2020

\section{R Arutselvan}

ICAR- Central Tuber Crops

Research Institute,

Thiruvananthapuram, Kerala,

India

\section{RD Prasad}

ICAR-Indian Institute of

Oilseeds Research,

Rajendranagar, Hyderabad,

Telangana, India

\section{G Uma Devi}

Professor, Jayashankar

Telangana State Agricultura

University, Rajendranagar,

Hyderabad, Telangana, India

C Sarada

ICAR-Indian Institute of

Oilseeds Research,

Rajendranagar, Hyderabad,

Telangana, India

Corresponding Author:

R Arutselvan

ICAR- Central Tuber Crops

Research Institute

Thiruvananthapuram, Kerala,

India

\section{Field evaluation of propiconazole fungicide against gray mold disease of castor}

\author{
R Arutselvan, RD Prasad, G Uma Devi and C Sarada
}

DOI: https://doi.org/10.22271/chemi.2021.v9.i1d.11236

\begin{abstract}
Castor (Ricinus communis L.), is an important non-edible oilseed crop which belongs to the family Euphorbiaceae which plays a vital role in Indian vegetable oil economy. Gray mold of castor is one of the major destructive fungal disease causing huge yield loss. The occurrence of gray mold is strongly governed by weather conditions. In on farm demonstrations on fungicidal management of gray mold conducted during kharif 2019 at different locations in Mahabubnagar dt. and IIOR farm fields. Prophylactic sprays of propiconazole fungicide $0.1 \%$ was given based on the alerts given by the decision support system (DSS) for gray mold developed by ICAR- IIOR based on weather data obtained from Wireless Sensors Networks (WSN) deployed in farmer's fields and observation on disease severity and seed yield were recorded manually in IIOR farms and farmer fields of Mahabubnagar district of Telangana state. The results revealed that two sprays of propiconazole @ $0.1 \%$ has recorded least percent disease severity and significantly increased the seed yield.
\end{abstract}

Keywords: Castor, gray mold, management, propiconazole

\section{Introduction}

Castor is one of the important commercial non-edible oilseed crops of India earning more than 4500 crores every year to the national exchequer. India is the leading producer of castor in the world (FAOSTAT, 2019) ${ }^{[4]}$ with an annual production of about $1.19 \mathrm{Mt}$. India accounts for nearly $73 \%$ of the world's production of castor (FAOSTAT, 2019) ${ }^{[4]}$. In India, castor is cultivated in an area of 7.6 lakh ha with 11.29 lakh tons of production and the average yield is $1520 \mathrm{Kg}$ ha-1 for the year 2018-2019 (SEA, 2019) ${ }^{[10]}$. Gujarat, Rajasthan and Andhra Pradesh are the major castor producing states of India. Andhra Pradesh accounts for 40 per cent of the total cultivated area. The important castor growing districts in Andhra Pradesh and Telangana states include Mahabubnagar, Kurnool, Ananthapur, Nalgonda and Prakasam. Gray mold caused by Botryotinia ricini is one of the very important diseases of castor inflicting huge yield losses to farmersin Telangana st. (Prasad et al, 2016) [9] when there is heavy and continuous rains during spike/ capsule formation stage. The prevalence of high relative humidity and prolonged wet conditions during flowering stage are congenial for pathogen development (Soares, 2012) ${ }^{[13]}$. At present, the management practices for this disease include application of fungicides like carbendazim before and after cessation of rains based on weather forecasting (Sudhakar et al. 2010; Prasad et al. 2016) ${ }^{[14,9]}$. But there is still a need to identify better fungicides for the management of $B$. ricini infection on castor under Telangana conditions. Use of chemical fungicides have shown efficacy of propiconazole against gray mold under experimental field conditions (Anonymous, 2018) [1]. Large scale on farm demonstrations have been taken up under farmers' fields in Mahabubnagar dt. And IIOR farms to showcase potential of the fungicide propiconazole in management of gray mold disease.

\section{Materials and Methods}

On farm demonstration of management of gray mold of castor using chemical fungicide has been taken up in farmer's field in narva manal of mahabubnagar district of Telangana state and IIOR farm fields during kharif 2019. In this experiment cv. DCH-519 were sown at the narva manal farmers field and research farms of ICAR-IIOR, Hyderabad in rows $0.9 \mathrm{~m}$ apart and 0.6 $\mathrm{m}$ between plants within the rows. Fungicides was used at their respective doses in the field conditions. 
The treatment (Fungicide) at the respective doses before application was mixed thoroughly with water and applied through power sprayer on racemes of castor as foliar sprays. Prophylactic sprays of propiconazole fungicide $0.1 \%$ was given based on the alerts given by the decision support system (DSS) for gray mold developed by ICAR-IIOR based on weather data obtained from Wireless Sensors Networks (WSN) deployed in IIOR farms and farmer fields of Mahabubnagar district of Telangana state. Later, the same fungicide was sprayed when the disease was initiated in the fields. However control was kept without any treatment only water was sprayed.

Data recorded: During the cropping season, observation on disease severity $(\%)$ and seed yield $(\mathrm{kg} / \mathrm{ac})$ were recorded at regular interval in IIOR farms and farmer fields of Mahabubnagar district of Telangana state.

Economics: Cost of cultivation (₹/ac) was calculated considering the prevailing charges of plant protection operations and market price of inputs involved. Gross returns were obtained by converting the harvest into monetary terms at the prevailing market rate during the course of study.

Gross return $(\mathrm{Rs} / \mathrm{ac})=($ Seed yield $\mathrm{x}$ price $)$

Net returns were obtained by deducting cost of cultivationfrom gross return Net returns $(\mathrm{Rs} / \mathrm{ac})=$ Gross return (Rs /ac) - Plant protection cost (Rs /ac)
The benefit: cost ratio was calculated by dividing Net returns by Plant protection cost

$$
\text { Benefit: Cost ratio }=\frac{\text { Net returns }(\mathrm{Rs} / \mathrm{ac})}{\text { Plant protection cost }(\mathrm{Rs} / \mathrm{ac})}
$$

\section{Results and Discussion}

During kharif 2019, Farmer's field in Mahabubnagar district of Telangana state gray mold severity in castor ranged from 24.1 to $26.5 \%$ and a seed yield recorded was between 515 and $580 \mathrm{~kg} / \mathrm{acre}$ in fields where one spray of Propiconazole fungicide $(0.1 \%)$ was taken up. In fields where fungicide was sprayed twice, a disease severity of 9.0 and $11.7 \%$ was recorded with 746 and $819 \mathrm{~kg} /$ acre seed yield was found most effective and proved to be most economical with higher benefit-cost ratio of $1: 4.4$ and 1:5.0 respectively. Disease severity ranging from 74.0 to $80.3 \%$ and seed yield between 186 and $215 \mathrm{~kg} /$ acre was recorded in unsprayed fields (Table 1 ). In ICAR-IIOR farm fields, where Propiconazole fungicide $(0.1 \%)$ was sprayed once a disease severity of $23.3 \%$ was recorded with $560 \mathrm{~kg} / \mathrm{acre}$ seed yield. In fields where fungicide was sprayed twice a disease severity of $9.2 \%$ was recorded with $812 \mathrm{~kg} /$ acre seed yield was found most effective and proved to be most economical with higher benefit-cost ratio of 1:4.9. Disease severity $72.2 \%$ and seed yield $202 \mathrm{~kg} /$ acre was recorded in unsprayed fields (Table 2). This significant difference indicates the efficacy and importance of timely spray of Propiconazole can reduce the disease severity and thereby increase the seed yield of the castor.

Table 1: On farm demonstration of efficacy of propiconazole fungicide on gray mold of castor (Narvamandal, Mahabubnagardt, Telangana)

\begin{tabular}{|c|c|c|c|c|c|c|c|c|c|}
\hline Location & Treatment & \begin{tabular}{|c|}
$\begin{array}{c}\text { Disease } \\
\text { severity } \\
(\%)\end{array}$ \\
\end{tabular} & $\begin{array}{c}\text { Seed } \\
\text { yield } \\
(\mathrm{kg} / \text { acre })\end{array}$ & $\begin{array}{c}\text { Increase in } \\
\text { yield over } \\
\text { control (kg/ac) }\end{array}$ & \begin{tabular}{|c|} 
Increase in \\
yield over \\
control $(\%)$ \\
\end{tabular} & $\begin{array}{c}\text { Cost of } \\
\text { increased } \\
\text { yield (Rs.) }(\mathrm{A})\end{array}$ & \begin{tabular}{|c|} 
Plant \\
protection \\
cost* (Rs.) (B)
\end{tabular} & $\begin{array}{l}\text { Net profit } \\
\text { (Rs.) A-B }\end{array}$ & ICBR \\
\hline \multirow{3}{*}{ Jaklair } & $\begin{array}{c}\text { Propiconazole } 1 \mathrm{ml} / 1 \text { (One } \\
\text { prophylactic spray based on weather } \\
\text { forecast) }\end{array}$ & 24.1 & 580 & 365 & 41.0 & 16,060 & 4500 & 11,560 & $1: 2.6$ \\
\hline & $\begin{array}{c}\begin{array}{c}\text { Propiconazole } 1 \mathrm{ml} / 1 \text { (Two sprays } \\
\text { based on weather forecast) }\end{array} \\
\end{array}$ & 10.3 & 805 & 590 & 63.5 & 25,960 & 4500 & 21,460 & $1: 4.8$ \\
\hline & Control(No sprays) & 74.0 & 215 & - & - & - & - & - & - \\
\hline \multirow{3}{*}{ Undyala } & $\begin{array}{c}\text { Propiconazole } 1 \mathrm{ml} / 1 \text { (One } \\
\text { prophylactic spray based on weather } \\
\text { forecast) } \\
\end{array}$ & 25.4 & 540 & 354 & 47.4 & 15,576 & 4500 & 11,076 & $1: 2.4$ \\
\hline & $\begin{array}{c}\text { Propiconazole } 1 \mathrm{ml} / \mathrm{l} \text { (Two sprays } \\
\text { based on weather forecast) }\end{array}$ & 11.7 & 746 & 560 & 66.8 & 24,640 & 4500 & 20,140 & $1: 4.4$ \\
\hline & Control(No sprays) & 80.3 & 186 & - & - & - & - & - & - \\
\hline \multirow{3}{*}{ Kanimetta } & $\begin{array}{c}\text { Propiconazole } 1 \mathrm{ml} / 1 \text { (One } \\
\text { prophylactic spray based on weather } \\
\text { forecast) }\end{array}$ & 26.5 & 515 & 313 & 35.4 & 13,772 & 4500 & 9,272 & $1: 2.1$ \\
\hline & $\begin{array}{c}\text { Propiconazole } 1 \mathrm{ml} / 1 \text { (Two sprays } \\
\text { based on weather forecast) }\end{array}$ & 9.0 & 819 & 617 & 67.2 & 27,148 & 4500 & 22,648 & $1: 5.0$ \\
\hline & Control(No sprays) & 75.6 & 202 & - & - & - & - & - & - \\
\hline
\end{tabular}

*Market price of castor: Rs.44/kg; Fungicide spray cost including /acre; 4500 included; ICBR = Net profit/Plant protection cost

Table 2: On farm demonstration of efficacy of propiconazole fungicide on gray mold of castor (IIOR, Hyderabad)

\begin{tabular}{|c|c|c|c|c|c|c|c|c|c|}
\hline Location & Treatment & \begin{tabular}{|} 
Disease \\
severity \\
$(\%)$
\end{tabular} & $\begin{array}{c}\text { Seed } \\
\text { yield } \\
(\text { kg/acre })\end{array}$ & \begin{tabular}{|c} 
Increase in yield \\
over control \\
$(\mathrm{kg} / \mathrm{ac})$
\end{tabular} & \begin{tabular}{|c|} 
Increase in \\
yield over \\
control $(\%)$ \\
\end{tabular} & $\begin{array}{c}\text { Cost of } \\
\text { increased yield } \\
(\text { Rs. })(\mathbf{A}) \\
\end{array}$ & $\begin{array}{l}\text { Plant protection } \\
\text { cost* (Rs.) (B) }\end{array}$ & $\begin{array}{l}\text { Net profit } \\
\text { (Rs.) A-B }\end{array}$ & ICBR \\
\hline \multirow{3}{*}{$\begin{array}{c}\mathrm{IIOR} \\
\text { research } \\
\text { farm }\end{array}$} & \begin{tabular}{|c|} 
Propiconazole \\
$1 \mathrm{ml} / 1($ One prophylactic spray \\
based on weather forecast)
\end{tabular} & 23.3 & 560 & 355 & 42.2 & 15,620 & 4500 & 11,120 & $1: 4.7$ \\
\hline & $\begin{array}{c}\text { Propiconazole } \\
1 \mathrm{ml} / \mathrm{l} \text { (Two sprays based on } \\
\text { weather forecast) }\end{array}$ & 9.2 & 812 & 607 & 66.2 & 26,708 & 4500 & 22,208 & $1: 4.9$ \\
\hline & Control (No sprays) & 72.2 & 205 & - & - & - & - & - & - \\
\hline
\end{tabular}

*Market price of castor: Rs.44/kg; Fungicide spray cost including /acre; 4500 included; ICBR = Net profit/Plant protection cost 
Management of botrytis diseases can be successfully achieved through application of chemical fungicides. However, foliar application of fungicides used at regular intervals with the first appearance of the Botrytis disease can control an epidemic in the crop (Pande et al., 2002) ${ }^{[8]}$. Similar effective fungicides can be used as a prophylatic spray to manage botrytis fungus include Carbendazim, Captan, Chlorothalonil, Mancozeb, Thiabendazole, Thiophanate-methyl, Thiram, Triadimefon, Triadimenol, or Vinclozolin (Singh and Kaur, 1990; Haware and McDonald, 1992; Bakr et al., 1993; Haware, 1998; Knights and Siddique, 2002; Pande et al., 2002; Davidson et al., 2004; Shahiduzzaman, 2015) [12, 6, 2, 5, 7, $8,3,11]$. Sometimes multiple sprays are recommended during favourable weather conditions, even though one spray at flowering stage followed by another spray 10 days later on a moderately resistant cultivar provides the best protection against gray mold infection on chickpea (Pande et al., 2002) [8].

\section{Conclusion}

The demonstrations on fungicidal management thus showed potential of the timely spray of fungicide propiconazole $(0.1 \%)$ in management of gray mold, realizing high seed yield and economic benefit to castor growers.

\section{References}

1. Anonymous. Annual progress report (2017-18). AICRP castor. Indian Institute of Oilseeds Research 2018,158.

2. Bakr MA, Rahman MM, Ahmed F, Kumar J. Progress in management of botrytis gray mold of chickpea in Bangladesh. In 'Recent advances in research in botrytis gray mold of chickpea'. Eds M, P. Haware, C.L.L. Gowda, D. McDonald 199,17-19.

3. Davidson JA, Pande S, Bretag TW, Lindbeck KD, Kishore GK. Biology and management of Botrytis spp. in legume crops. In 'Botrytis: biology, pathology and control'. (Eds Y. Elad, B. Williamson, P. Tudzynski, N. Delen) 2004,295-318.

4. FAOSTAT. Food and Agriculture Organization of the United Nations, Rome 2019. www.fao.org/faostat/en/\#d ata/Q C/. Accessed 6 March 2020

5. Haware MP. Diseases of chickpea. In 'The pathology of food and pasture legumes'. (Eds D.J. Allen and J.M. Lenne) 1998,473-516.

6. Haware MP, McDonald D. Integrated management of botrytis gray mold of chickpea. In 'Botrytis gray mold of chickpea'. Eds M.P. Haware, D.G. Faris and C.L.L. Gowda 1992,3-6.

7. Knights EJ, Siddique KHM. Manifestation of Botrytis cinerea on chickpeas in Australia. In 'Workshop Proceedings Integrated Management of Botrytis Grey Mould of Chickpea in Bangladesh and Australia' 2002,70-77.

8. Pande S, Singh G, Rao JN, Bakr MA, Chaurasia PCP, Joshi $\mathrm{S}$ et al. Integrated management of botrytis gray mold of chickpea. Information Bulletin No. 61, ICRISAT, Andhra Pradesh, India 2002.

9. Prasad RD, Raoof MA, Senthilvel S, Dinesh Kumar V, Praduman Y, Bhuvaneswari R et al. Gray mold of castorTechnical bulletin. Indian Institute of Oilseeds Research, Hyderabad 2016,1-40.

10. SEA, SEA Castor crop survey 2018-19. The Solvent Extractors Association of India, Mumbai, India 2019.
11. Shahiduzzaman M. Efficacy of fungicides in controlling Botrytis. Bangladesh Journal of Agricultural Research 2015;40(3):391-398.

12. Singh G, Kaur L. Chemical control of gray mold of chickpea. Plant Disease Research. 1990;5:132-137.

13. Soares DJ. The gray mold of castor bean: A review. InTech Publisher, Rijeka, Croatia 2012.

14. Sudhakar R, Khayum Ahammed S, Meena Kumari K, Srinivas T, Vishnuvardhan Reddy A. Integrated disease management of botrytis grey rot of castor (Ricinus communis L.). Journal of Oilseeds Research 2010;27:239-240. 